\title{
DE FISCALE EENHEID IN DE WET OP DE VENNOOTSCHAPSBELASTING 1969 DE ONTWIKKELINGEN SINDS 1975
}

\author{
door Mr.J. G. Verseput
}

\section{Wijzigingen van de standaardvoorwaarden in 1976 en 1978}

In het februari-nummer van 1975 van dit maandblad verscheen een artikel van mijn hand, waarin de regeling van de fiscale eenheid in de Wet op de Vennoot. schapsbelasting 1969 is uiteengezet.

Sindsdien zijn twee gewijzigde versies van de standaardvoorwaarden versche. nen als bijlagen bij de aanschrijvingen van 27 februari 1976') en van 22 augustus $1978^{2}$ ). Voorts heeft de staatssecretaris in deze aanschrijvingen wederom een aantal departementale opvattingen kenbaar gemaakt.

Hierna volgt een overzicht van de wijzigingen.

\section{De 17e standaardvoorwaarde}

Deze voorwaarde is voor het eerst in 1976 opgenomen en overgenomen in de in 1978 gepubliceerde standaardvoorwaarden.

De tekst van de voorwaarde luidt als volgt:

„Indien de samenstelling van het vermogen van de dochtermaatschappij is gewijzigd ten gevolge van transacties binnen de fiscale eenheid en aannemelijk is dat een bedrag ter grootte van de tegenwaarde van de stille reserves, inclusief goodwill, die onmiddellijk na de laatste transactie in de dochtermaatschappij aanwezig zijn, dan wel een bedrag ter grootte van een deel daarvan, anders dan door verkoop van de aandelen in de dochtermaatschappij ten goede is gekomen aan de moedermaatschappij en/of de naamloze vennootschap of besloten vennootschap met beperkte aansprakelijkheid die met haar verenigd is of is geweest, voordat sindsdien zes boekjaren zijn geëindigd, worden bij het einde van het boekjaar dat onmiddellijk aan het splitsingstijdstip voorafgaat de activa en de passiva van de dochtermaatschappij alsnog gesteld op de waarde in het economisch verkeer. Het bepaalde in de vorige volzin vindt geen toepassing indien de daarbedoelde transacties uitsluitend plaatsvinden in het kader van een bij de aard en de omvang van de dochtermaatschappij passende normale bedrijfsuitoefening."

De 17e voorwaarde vormt een uitbreiding op de $16 \mathrm{e}$ voorwaarde en heeft, evenals deze laatste, ten doel belastingvrije realisatie van gedeelten van het ondernemingsvermogen met behulp van een fiscale eenheid, te voorkomen.

Aan de hand van het volgende voorbeeld kan dit worden verduidelijkt:

De B.V. Hotelexploitatie heeft een hotelpand waarin grote stille reserves schuil gaan. De fiscale balans van de vennootschap ziet er als volgt uit:

\footnotetext{
1) O.m. gepubliceerd in BNB 1976/119 en in Vakstudie.Nieuws van 27 maart 1976.

2) O.m. gepubliceerd in BNB 1978/266 en in Vakstudie. Nieuws van 80 september 1978.
} 
Men wil nu het hotelpand voor 1.300 verkopen aan de B.V. Vastgoed.

De B.V. Hotelexploitatie richt daartoe een dochtervennootschap op, „Hotel B.V.", met een kapitaal van 100, waarin zij alle aandelen krijgt. Tussen B.V. Hotelexploitatie en Hotel B.V. wordt een fiscale eenheid aangevraagd. Binnen de fiscale eenheid wordt het hotelpand door B.V. Hotelexploitatie aan Hotel B.V. overgedragen voor 1.300 .

Ervan uitgaande dat de latente belastingverplichting op 20\% kan worden gesteld ziet de commerciële balans van de nieuwe vennootschap er dan als volgt uit:

Hotelpand

\begin{tabular}{l}
1.300 \\
1.300 \\
\hline
\end{tabular}

Aandelenkapitaal

Latente belasting

verplichtingen

Schuld aan B.V.

Hotelexploitatie

Omdat deze transactie binnen de fiscale eenheid tot stand kwam kan de tot uitdrukking gebrachte meerwaarde niet worden belast.

$\mathrm{Nu}$ lijkt het er op dat in het volgende jaar B.V. Hotelexploitatie de aandelen in Hotel B.V. aan de B.V. Vastgoed zonder problemen voor 100 zou kunnen verkopen. Voor deze aandelen werd immers ook 100 als kapitaalstorting betaald. Zo eenvoudig ligt het echter niet:

Door de verkoop van de aandelen Hotel B.V. wordt de fiscale eenheid tussen B.V. Hotelexploitatie en Hotel B.V. met terugwerkende kracht tot 1 januari van het jaar van verkoop, verbroken. Volgens de elfde standaardvoorwaarde dient het op het splitsingstijdstip voor de aandelen in Hotel B.V. opgeofferde bedrag te worden gesteld op het fiscaal vermogen van Hotel B.V. op dat tijdstip.

De fiscale openingsbalansen van de beide vennootschappen zien er op dat moment dan als volgt uit:

\section{B.V. Hotelexploitatie}

Aandelen in Hotel B.V. neg. 700

Fiscaal vermogen

Schulden

Vordering op Hotel B.V. $\quad 1.000$

Overige activa 
Bij de verkoop van de aandelen Hotel B.V. maakt de B.V. Hotelexploitatie dus een fiscale winst van $100-$ (neg. 700) $=800$. In beginsel valt deze winst onder de deelnemingsvrijstelling, doch de in mijn artikel van februari 1975 besproken $16 \mathrm{e}$ standaardvoorwaarde sluit de toepassing van deze vrijstelling uit. Het ministerie acht het in strijd met het wettelijke systeem indien het door middel van een fiscale eenheid mogelijk zou zijn te komen tot belastingvrije realisatie van stille reserves, ook al zou de latente belastingclaim daarbij in stand blijven.

De werking van de $16 \mathrm{e}$ standaardvoorwaarde kan echter worden ontweken door niet over te gaan tot verkoop van de aandelen in de dochtermaatschappij Hotel B.V. - hetgeen tot belastingheffing zou leiden - maar tot bijplaatsing van een zodanig aantal aandelen in deze vennootschap bij de „koper” dat deze daardoor nagenoeg het gehele belang in die vennootschap verkrijgt.

In het voorbeeld verloopt dit als volgt:

Hotel B.V. plaatst in het jaar volgend op dat, waarin zij het pand kocht, nom. 1.000 aandelen tegen een koers van $100 \%$ bij Vastgoed B.V., de gegadigde voor het hotelpand. Hierna zijn gerechtigd in Hotel B.V., Vastgoed B.V. voor $f 1.000$ aandelen en B.V. Hotelexploitatie voor $f 100$ aandelen.

Hotel B.V. gebruikt de kapitaalstorting van $f 1.000$ om daarmee haar schuld aan B.V. Hotelexploitatie af te lossen. Met name deze aflossing uit de door bij. plaatsing verkregen gelden stelt de bijplaatsing van aandelen naar de mening van het ministerie nagenoeg op één lijn met de rechtstreekse verkoop van de aandelen

$\mathrm{Na}$ genoemde transactie blijft de deelneming van B.V. Hotelexploitatie in Hotel B.V. weliswaar te boek staan voor negatief 700 (werkelijke waarde 100), doch na verloop van de in de $16 \mathrm{e}$ standaardvoorwaarde genoemde strafperiode van 5 jaar kan dit belang onder de alsdan weer van toepassing zijnde deelnemings. vrijstelling aan Vastgoed B.V. worden verkocht.

De nieuwe 17e standaardvoorwaarde beoogt dergelijke transacties tegen te gaan door in deze situaties tot belastingheffing te geraken.

De voorwaarde werkt indien aan de volgende cumulatieve voorwaarden is vol. daan:

a. binnen de fiscale eenheid hebben transacties plaatsgevonden waarbij de dochtermaatschappij betrokken was en die niet pasten in de normale bedrijfs. uitoefening van de dochtermaatschappij;

b. voordat sinds de (laatste) transactie 6 boekjaren zijn geëindigd is de tegenwaarde van de onmiddellijk na de transactie bij de dochtermaatschappij aanwezige stille reserves geheel of gedeeltelijk aan de moedermaatschappij ten goede gekomen. Met de term „ten goede komen" wordt niet alleen gedoeld op het aflossen van de vordering, maar onder meer ook op de volgende situaties:

- verkoop van de vordering

- belening van de vordering 
- het betalen van een hogere rente over de vordering dan de marktrente

- het betalen van een hoger dividend op de aandelen in handen van B.V. Hotelexploitatie dan door de winst van Hotel B.V. wordt gerechtvaardigd.

c. De fiscale eenheid is beëindigd. Plaatsing van aandelen bij derden heeft tot gevolg dat de fiscale eenheid wordt beëindigd, met ingang van het jaar waarin is bijgeplaatst.

Indien aan vorenstaande voorwaarden is voldaan worden de activa en passiva van de dochtermaatschappij bij het einde van het boekjaar dat onmiddellijk aan het splitsingstijdstip voorafgaat gesteld op de waarde in het economisch verkeer.

Met andere woorden:

Indien in vorenstaand voorbeeld bijplaatsing van aandelen heeft plaatsgevonden in 1979 wordt de fiscale eenheid met ingang van 1.1.1979 verbroken. Door dat er met activa en passiva is geschoven zodanig dat de stille reserves ten goede zijn gekomen aan de moedermaatschappij - in de zin als hiervoor omschreven zal het hotelpand per 31 december 1978 fiscaal te boek moeten worden gesteld voor de waarde in het economisch verkeer (1.300), zodat de stille reserve (1.000) nog binnen de fiscale eenheid in 1978 wordt belast.

Daar het „ten goede komen" veelal eerst na het splitsingstijdstip zal optreden zal de heffing op grond van de 17e standaardvoorwaarde in meerdere gevallen bij navordering moeten plaatsvinden.

Bedacht moet worden dat de $17 \mathrm{e}$ voorwaarde ook werkt in gevallen waarin niet op een belastingvrije realisatie van stille reserves wordt aangestuurd.

Bij iedere ontvoeging van een fiscale eenheid, ook in situaties waarbij de ontvoeging plaatsvindt op verzoek en niet het gevolg is van een vervreemding van aandelen in de dochter door de moedervennootschap, dient daarom nagegaan te worden of genoemde standaardvoorwaarde niet tot belastingheffing aanlei ding kan geven. In vele gevallen zal vooroverleg met inspecteur of Ministerie van Financiën wenselijk zijn.

Bij overdracht van een onderneming of een zelfstandig onderdeel daarvan aan een dochtervennootschap heeft men de keus tussen overdracht binnen fiscale eenheid dan wel geruisloze inbreng op de voet van artikel 14 van de Wet op de Vennootschapsbelasting 1969. De 17e standaardvoorwaarde vormt een zodanige verscherping van het regiem van de fiscale eenheid dat in een toenemend aantal gevallen de voorkeur zal uitgaan naar inbreng met toepassing van artikel 14 .

\section{Nadere uitleg van het begrip ,,alle aandelen"}

Een van de door de Wet gestelde voorwaarden voor fiscale eenheid is dat de moe. dermaatschappij alle aandelen bezit in de dochtermaatschappij. Door de minister is de eis van ,alle aandelen” verzwakt tot tenminste $99 \%$, terwijl voor de bepaling van dit percentage zoek geraakte aandelen niet behoeven te worden meegeteld.

Daarbij is gedacht aan vennootschappen met één soort aandelen en niet aan vennootschappen met verschillende soorten aandelen die ongelijk over de aandeelhouders zijn verdeeld.

Te denken valt aan een dochtermaatschappij waarvan het aandelenkapitaal voor $99 \%$ bestaat uit preferente aandelen, die slechts recht geven op het nominaal 
gestorte kapitaal, en voor $1 \%$ uit aandelen die gerechtigd zijn tot het gehele overige vermogen.

In de resolutie van 1976 heeft de minister te kennen gegeven dat in dergelijke gevallen een fiscale eenheid - uiteraard - niet mogelijk is indien de moedermaatschappij slechts de preferente aandelen bezit. De $99 \%$ eis is daarom door de minister verder gepreciseerd. De moedermaatschappij dient in het bezit te zijn van tenminste $99 \%$ van het geplaatste en gestorte aandelenkapitaal in de dochter. maatschappij met dien verstande dat het ontbrekende aandeel of de ontbrekende aandelen tezamen niet meer rechten mogen geven op het vermogen of de winst van de dochtermaatschappij dan overeenkomt met $1 \%$ van dat vermogen of die winst.

\section{Fiscale eenheid en WIR}

In 1978 zijn de standaardvoorwaarden aangepast naar aanleiding van de totstand. koming van de Wet Investeringsrekening.

Deze aanpassing omvat de invoering van de letters $d$, e en fin de $4 \mathrm{e}$ standaard. voorwaarde. Deze bepalingen bevatten eenzelfde regeling als voor de investeringsaftrek gold. Bij voeging gaan nog niet uitgewerkte aanspraken op een inves. teringsbijdrage en latente verplichtingen tot desinvesteringsbetaling over op de combinatie. Bij splitsing vindt deze overgang plaats naar de maatschappij tot wier vermogen het bedrijfsmiddel waarmede de aanspraak/verplichting verband houdt op het splitsingstijdstip behoort.

De problematiek rond fiscale eenheid en WIR is daarmede echter niet uitgeput.

Als gevolg van de werking van een fiscale eenheid worden alle bezittingen, schulden en handelingen van de dochter aan de moeder toegekend. De dochter is fiscaalrechtelijk in de moeder opgegaan.

Dit betekent dat transacties binnen de fiscale eenheid uitsluitend als interne mutaties worden aangemerkt. Deze transacties kunnen dan ook geen aanleiding geven tot investeringsbijdragen dan wel desinvesteringsbetalingen.

Op grond van hetzelfde beginsel kan binnen een fiscale eenheid geen sprake zijn van ter beschikking stellen van een bedrijfsmiddel door de ene maatschappij aan de andere. Verhuur van bijvoorbeeld een pand door de moedermaatschappij aan een dochter is binnen de fiscale eenheid een handeling welke wordt genegeerd.

In de gevallen waarin het recht op investeringspremie afhankelijk is van de vraag of het bedrijfsmiddel bestemd is om hoofdzakelijk ter beschikking te worden gesteld aan derden (art. 61 a lid 5 letter i van de Wet op de Inkomstenbelasting 1964 en art. 23d leden 1 en 2 van de Wet op de Vennootschapsbelasting 1969) dient op het tijdstip van de investering te worden beoordeeld of aan de wettelijke vereisten is voldaan.

De vraag is of op dat moment met een latere fiscale eenheid, waardoor niet meer van ter beschikking stellen sprake is, dan wel met een latere ontvoeging, waardoor een situatie ontstaat waarin van ter beschikking stellen sprake is, rekening mag worden gehouden.

Bij de beoordeling van de bestemming is niet beslissend de feitelijke situatie bij de ingebruikname van het bedrijfsmiddel doch is beslissend de aard van het, 
op het moment van investeren, te verwachten gebruik in de komende jaren.

Indien dan ook ten tijde van het investeren de latere fiscale eenheid of ontvoe. ging viel te verwachten dient met deze omstandigheid rekening te worden gehouden bij de beoordeling van het criterium: hoofdzakelijk ter beschikking stellen aan derden.

Een latere wijziging van de bestemming door het ter beschikking stellen aan derden kan aanleiding geven tot desinvesteringsbetaling en wel in de gevallen genoemd in art. 61 a lid 5, letter i van de Wet op de Inkomstenbelasting 1964. Daar. bij moet aan verdere vereisten worden voldaan (gebruik in het bosbedrijf, de der. de is een niet belastingplichtig lichaam etc.).

Men kan zich afvragen of de ontbinding van een fiscale eenheid, waarna weer sprake is van een ter beschikking stellen, aangemerkt kan worden als een bestem. mingswijziging. De vraag of dit aanleiding geeft tot desinvesteringsbetaling zal zich in de praktijk echter niet snel voordoen. Indien na de splitsing aan de vereisten van art. 6 la lid 5, letter i wordt voldaan zal het bedrijfsmiddel voor de splitsing gewoonlijk reeds gevallen zijn onder de werking van letter $\mathrm{h}$ van dit artikel.

Opmerking verdient tenslotte dat ingevolge artikel 1 van de Wet Investeringsre. kening de fiscale eenheid ook voor het niet fiscale gedeelte van deze wet van toepassing is. Gelet op de wijze van totstandkoming van een fiscale eenheid, op ver. zoek van de belastingplichtige en na aanvaarding van aan hem gestelde voorwaarden, is het de vraag of, zeker voor reeds bestaande fiscale eenheden, aan de werking van de fiscale eenheid bij Wet een uitbreiding kan worden gegeven bui. ten het terrein van de vennootschapsbelasting. 